\title{
DENTAL HEALTH OF FIVE-YEAR-OLD CHILDREN IN MAZOWIECKIE PROVINCE AS REVEALED BY MONITORING OF DENTAL HEALTH AND ITS DETERMINANTS IN 2011 AND 2016
}

\author{
Małgorzata Dudek', Iwona Soika' ${ }^{1}$, Weronika Jończyk ${ }^{1}$, Anna Turska-Szybka' ', Dariusz Gozdowski², Dorota Olczak-Kowalczyk \\ 'Department of Pediatric Dentistry, Medical University of Warsaw, Poland \\ 2Department of Experimental Design and Bioinformatics, Faculty of Agriculture and Biology, Warsaw University of Life Sciences, Poland
}

\begin{abstract}
INTRODUCTION: Epidemiology surveys conducted periodically in the same age groups allow assessment of the rate of changes in the burden of caries as well as the needs concerning prophylaxis and treatment. They also indicate the necessary course of action with regard to the promotion of oral health.

Овjectives: The aim of the study was to perform a comparative assessment of the dental health and the needs with regard to caries treatment in 5-year-old children in Mazowieckie Province in 2011 and 2016.

MATERIAL AND METHODS: An analysis was conducted of the results of the epidemiological surveys of children aged five years conducted in Mazowieckie Province in 2011 and 2016 within the framework of Monitoring of Dental Health and Its Determinants. The analysis compared the prevalence and severity of caries (dmft/DMFT), the values of care indices and the needs with regard to treatment of caries and its complications. The statistical analysis employed the $\mathrm{t}$-test to compare the means between the groups and the $\chi^{2}$ test to compare the percentages. The analyses were performed using Statistica 12 software.

RESULTS: Over a period of five years, the percentage of children free from caries in Mazowieckie Province increased from $18.8 \%$ to $21.7 \%$. In 2011, the dmft index was 6.02 and decreased in 2016 to the value of $5.33 \pm 4.58$. In 2011 , the $\mathrm{SiC}$ index was 10 and the $\mathrm{dmft}$ index for the remaining $2 / 3$ of the study group was 2.2 . In $2016, \mathrm{SiC}$ increased slightly, reaching the value of $10.75 \pm 2.53$, while $\mathrm{dmft}$ for the remaining $2 / 3$ of the study group was $2.61 \pm 2.45$. The percentage of children in whom no treatment needs were identified increased from $22.7 \%$ in 2011 to $24.3 \%$ in 2016 .

Conclusions: Despite the fact that the needs for care due to dental caries in 5-year-old children were satisfied at a similarly low level in 2011 and 2016, the values of indices concerning dental caries in primary and permanent teeth and the needs for treatment of extensive carious cavities and pulp pathology were decreased. The increase in caries polarisation in primary teeth stresses the necessity of continued monitoring of this population in order to develop tools that will enable a systemic approach to distinguishing groups of children that require enhanced preventive and curative measures.
\end{abstract}

KEY WORDS: 5-year-old children, caries disease, primary teeth, epidemiological surveys.

J Stoma 2018; 71, 3: 268-272

DOI: https://doi.org/10.5114/jos.2018.80644

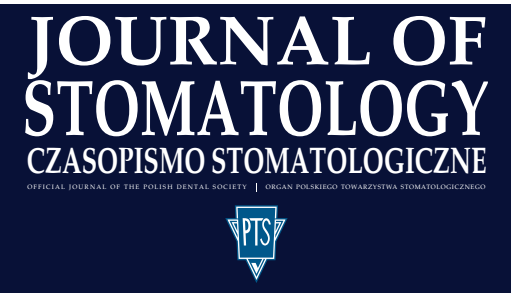

ADDRESS FOR CORRESPONDENCE: Małgorzata Dudek, Department of Pediatric Dentistry at the Medical University of Warsaw, 18 Miodowa St., 00-246 Warsaw, phone: +48 2250220 31, fax: +48 2250220 30, e-mail: pedodoncja@wum.edu.pl 


\section{INTRODUCTION}

The surveys conducted within the framework of Monitoring of Dental Health and Its Determinants reveal significant regional differences in the prevalence and severity of dental caries. Mazowieckie Province belongs to those regions of Poland where the burden of caries disease, especially in the primary dentition, is greater than the average value for the whole country. According to the results of nation-wide studies from 2011 conducted in 16 provinces, the percentage of children aged 5 free from caries in Mazowieckie Province was lower than percentage for the whole of the country (18.8\% vs. $20.1 \%$ ) and lower than the percentage in eight other provinces [1]. The severity of caries in primary teeth was among the highest $(\mathrm{dmft}=6.02)$. A higher value of the dmft index was only found in WarmińskoMazurskie Province (7.18). At the same time, Mazowieckie Province was among the three provinces where the needs concerning the care of primary teeth were satisfied to a larger extent than in the majority of provinces and in comparison with the mean for the entire country (16\% for Mazowieckie vs. $11 \%$ for the whole country) [1]. These data emphasise the importance of children's lifestyles in the aetiology of early childhood caries and the necessity of pro-health education for both the children and their carers. In 2012, the educational programme 'Caries-Free Childhood' was initiated in the area of Mazowieckie Province within the framework of Polish-Swiss collaboration. The programme was aimed at pre-school children, their parents, carers and educators as well as physicians and nurses providing medical care of children. Its first effects can already be seen in the epidemiological survey carried out in 2016.

\section{OBJECTIVES}

The aim of the study was to perform a comparative assessment of dental health and treatment needs for dental caries in 5-year-old children in Mazowieckie Province in 2011 and 2016.

\section{MATERIAL AND METHODS}

A comparative analysis was conducted on the results of the epidemiological surveys from 2011 and 2016 carried out among 5-year-old children within the framework of Monitoring of Dental Health and Its Determinants in Mazowieckie Province. The study was conducted in compliance with the requirements and based on the diagnostic criteria for clinical conditions according to the WHO guidelines $[2,3]$. The study was approved by the Bioethics Committee at the Medical University of Warsaw, No. KB/190/2016 of 06.09.2016 and No. KBO/36/11 of 20.09.2011, and was conducted in compliance with the Declaration of Helsinki.
A comparison was made of the number of children in the study and their teeth, the prevalence of early childhood caries and permanent teeth caries, the values of the $\mathrm{dmft} /$ DMFT indices, the Care Index for caries as well as the needs concerning treatment of caries and its complications. The values of the above-mentioned parameters of oral health obtained in the surveys in 2011 and 2016 were compared with reference to whole study groups, and in 2016 also taking into account the place of residence (urban area/ rural area) and the gender of the subjects.

The statistical analysis was conducted using the t-test to compare the means between the groups and the $\chi^{2}$ test to compare the percentages. The analyses were performed using Statistica 12 software.

\section{RESULTS}

In 2011, the size of the study group of children in Mazowieckie Province was 128, and in 2016 it was 223. The characteristics of the study groups are presented in Table 1 . The results of the survey conducted in $2011 \mathrm{did}$ not take into account the distribution of the children's gender and places of residence.

In five years, the percentage of children free from caries in Mazowieckie Province increased from $18.8 \%$ in 2011 to $21.7 \%$ in 2016 (Figure 1). In 2011, 55.5\% of children had four or more decayed teeth ( $\mathrm{dt} \geq 4)$. In 2016, $\mathrm{dmft} \geq 4$ was found in 132 of 230 children (57.4\%).

The indicator of caries severity in primary teeth, expressed as the mean dmft score, in Mazowieckie Province in 2011 was 6.02 and in 2016 it decreased to 5.33 \pm 4.58 . The percentage distribution for the individual $\mathrm{dmft}$ component indices also changed over the years 2011-2016 (Figure 2).

These changes were, however, not statistically significant $(p>0.05)$. The main component of the $\mathrm{dmft}$ index

TABLE 1. Characteristics of examined groups of children in 2011 and 2016

\begin{tabular}{|c|c|c|c|}
\hline & 2011 & \multicolumn{2}{|c|}{2016} \\
\hline $\begin{array}{c}\text { Number of examined } \\
\text { children }\end{array}$ & 128 & \multicolumn{2}{|c|}{223} \\
\hline Place of residence & No data & $\begin{array}{c}\text { City } \\
116(52.0 \%)\end{array}$ & $\begin{array}{c}\text { Village } \\
107(48.0 \%)\end{array}$ \\
\hline Sex & No data & $\begin{array}{c}\text { Girls } \\
110(49.3 \%)\end{array}$ & $\begin{array}{c}\text { Boys } \\
113(50.7 \%)\end{array}$ \\
\hline $\begin{array}{l}\text { Number of children } \\
\text { with at least one } \\
\text { permanent tooth } \\
\text { exfoliated }\end{array}$ & $40(31.3 \%)$ & \multicolumn{2}{|c|}{$59(25.7 \%)$} \\
\hline $\begin{array}{l}\text { Average number of } \\
\text { deciduous teeth }\end{array}$ & 19.21 & \multicolumn{2}{|c|}{$19.34 \pm 1.21$} \\
\hline $\begin{array}{l}\text { Average number of } \\
\text { permanent teeth }\end{array}$ & No data & \multicolumn{2}{|c|}{$0.78 \pm 1.58$} \\
\hline
\end{tabular}




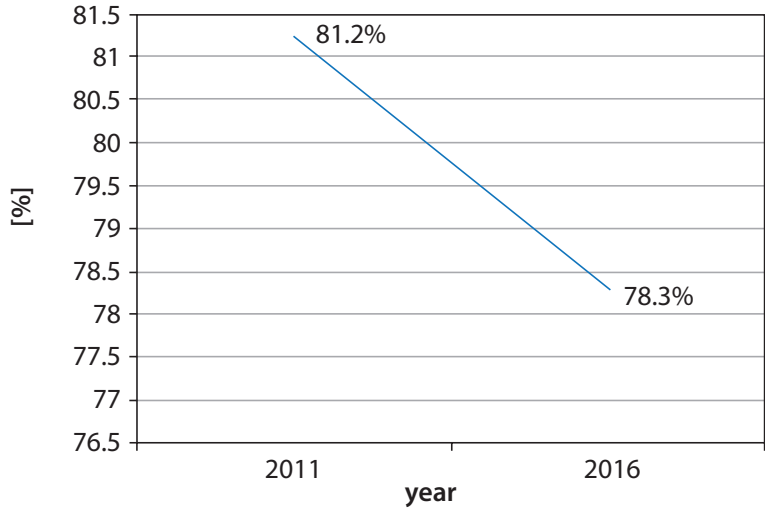

FIGURE 1. Percentage of children with DMFT $>0$ in 2011 and 2016

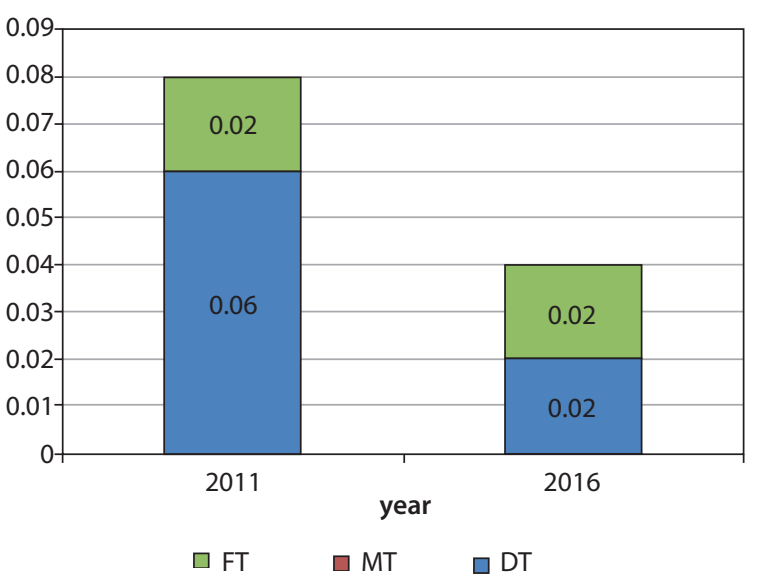

FIGURE 3. DMFT index and its components in 2011 and 2016 in Mazovia Province

in both studies was the dt component (5.03 in 2011 and $4.50 \pm 4.38$ in 2016 , respectively). An increase was also observed in the percentage of children with at least one primary tooth missing due to caries, from $4.7 \%$ in 2011 to $7.0 \%$ in 2016 . However, the Care Index value for primary teeth did not change and was 0.16 in both 2011 and 2016 .

In 2016, no statistically significant differences were found in the dmft index comparing either gender (girls vs. boys: $4.89 \pm 4.55$ vs. $5.75 \pm 4.58, p=0.157$ ) or the place of residence (urban vs. rural: $5.05 \pm 4.44$ vs. $5.70 \pm 4.74, p=0.286$ ). However, higher values can be observed in boys and in rural dwellers.

The values of the significant caries index were also similar. In 2011, it was 10, and the $\mathrm{dmft}$ index for the remaining $2 / 3$ of the study group was 2.2. In 2016, it rose slightly, reaching the value of $10.75 \pm 2.53$, while the $\mathrm{dmft}$ for the remaining $2 / 3$ of the study group was $2.61 \pm 2.45$.

In 2016, a statistically significantly greater number of permanent teeth was observed in girls than in boys $(0.99 \pm 1.79$ vs. $0.58 \pm 1.33 ; p=0.048)$, irrespec-

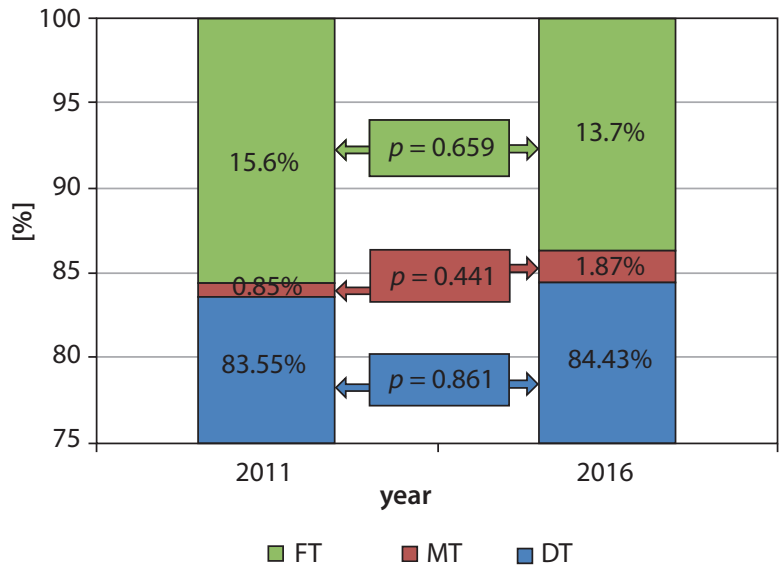

FIGURE 2. Components of DMFT index in 2011 and 2016

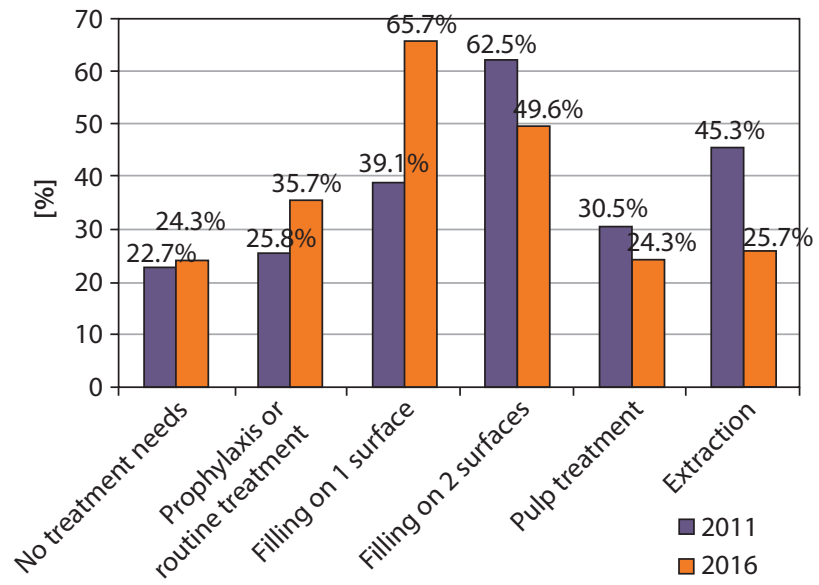

FIGURE 4. Treatment needs in 5-year-old children in Mazovia Province in 2011 and 2016

tive of the place of residence $(0.68 \pm 1.44$ urban vs. $0.90 \pm 1.74$ rural; $p=0.290$ ). The percentages of children with at least one permanent tooth in urban areas (27.5\%) and in girls (30.6\%) were higher than in the urban areas (24.2\%) and in boys (21.0\%) but the differences were not statistically significant.

Over the period of five years, the rate of severity of dental caries in permanent teeth decreased two-fold among 5-year-old children in Mazowieckie Province. The value of the DMFT index in 2011 was assessed at $0.08(\mathrm{DT}=0.06, \mathrm{FT}=0.02)$ and in 2016 at $0.04 \pm 0.31$ $(\mathrm{DT}=0.02 \pm 0.16, \mathrm{FT}=0.02 \pm 0.17)$ (Figure 3 ).

The analysis of the needs concerning prophylaxis and treatment revealed a slight increase in the percentage of children without such needs and with needs concerning prophylaxis and making a filling on one tooth surface (Figure 4). On the other hand, as many as $62.5 \%$ of children in 2011 and $49.6 \%$ in 2016 needed fillings on two surfaces. The percentages of children requiring treatment of pulpal diseases and extraction of at least one tooth also decreased (Figure 4). 


\section{DISCUSSION}

The year 2011 was the first in which children aged 5 were included in the nationwide epidemiology survey [1]. The inclusion of 5-year-old children in index age groups enables observation of the prevalence of dental caries in primary teeth in the whole population since permanent teeth are found in only a small number of children at this age in contrast to 6- and 7-year-olds. Thus far, 5 -year-old children have been included in epidemiology surveys twice, but even this number of studies allows for a comparison and drawing conclusions concerning dental health in small children in our country.

The percentage of 5-year-old children free from dental caries slightly increased in Mazowieckie Province over the past five years, from $18.8 \%$ to $21.7 \%$; nevertheless, this is still a very low figure as compared with the majority of European countries [1,4]. For instance, in Scotland the percentage of 5- and 6-year-old children free from dental caries in 2014 was as high as 68\% [5]. In England, Wales and Northern Ireland, in a 2013 survey, the percentage of 5-year-old children free from dental caries reached $40 \%$ [6]. Percentages of children free from dental caries comparable with that for Poland were observed in Kuwait in 2010, where $\mathrm{dmf}=0$ was observed in $24 \%$ of 5 -year-olds, and in Albania in 2017 , where absence of decayed teeth $(d=0)$ was found in $20.1 \%$ of small children [7,8]. Higher prevalence of dental caries disease was found in Kosovo in 2011, in $91.2 \%$ of children aged 2 to 6 [9]. An example for other countries may be Sweden, where a very large increase in the percentage of 5-year-old children free from dental caries was observed over 40 years, from 9\% in 1973 to $69 \%$ in 2013 [10].

While the drop in the prevalence of dental caries disease among 5-year-old children in Mazowieckie Province is a positive trend, the increase in the $\mathrm{SiC}$ index value over 5 years, from 10 in 2011 to $10.75 \pm 2.53$ in 2016, is certainly a negative phenomenon $[1,4]$. This points to a growing polarisation of caries; there are fewer children affected by dental caries disease but its intensity is higher in those in whom it occurs.

In 2016, the dmft index reached $5.33 \pm 4.58$ in Mazowieckie Province, one of the highest values among all the provinces in the survey (mean $\mathrm{dmft}$ for the entire study population in four provinces was $4.70 \pm 4.33$ ) [4]. This can be compared with neighbouring Germany, where a survey conducted in 2015 on 496 five-year-old children revealed the mean $\mathrm{dmft}$ index for the entire population at $0.9 \pm 2.0$ [11]. In 5-year-olds in the United Arab Emirates in 2010, the mean dmft index was $4.0 \pm 4.1$; likewise, in Saudi Arabia in 2003, in pre-school children it was $4.80 \pm 4.87$, but this increased to $6.1 \pm 3.9$ in 2008 [12-14]. Lower dmft index was found in India, in 5-year-old children in retrospective surveys in 2000$2015-2.49 \pm 7.78$ [15]. The dmft index similar to that for Mazowieckie Province was found among children aged 5-6 in 2006-2015 in the territory of South-East Asia $-5.1[16]$.

Also the percentage of 5-year-old children with at least one primary tooth missing due to caries in 2016 was the highest in Mazowieckie Province of all the provinces in the survey, and reached 7\%, while in Dolnośląskie Province it was twice as low (3.2\%). The percentage was the lowest in the Lubelskie and Małopolskie provinces - 1.8\% [4].

The two-fold decrease in the level of caries severity in permanent teeth in 5-year-old children is a positive phenomenon. In our province, $25.7 \%$ of 5 -year-olds have at least one erupted permanent tooth. In 2016, it was only in Mazowieckie Province that the index of permanent teeth filled due to dental caries was higher than zero (FT $=0.02 \pm 0.17$ ), while in the other provinces (Małopolskie, Dolnośląskie and Lubelskie) the only DMFT component was that of permanent teeth manifesting caries $[1,4]$.

The high treatment needs among 5-year-old children in Mazowieckie Province were not satisfied either five years ago or at present. A positive phenomenon, however, is the drop in the rate of needs concerning extensive fillings and treatment of dental caries complications. Nevertheless, in 2016 as many as $65.7 \%$ of children needed a filling on one tooth surface and $49.6 \%$ on two surfaces. In Mazowieckie Province, in 2016, the $\mathrm{ft}$ component index was $0.7 \pm 1.5$, while in Bosnia and Herzegovina it was $1.3 \pm 2.4$ [17]. The care index (CI) for primary teeth in Mazowieckie Province, expressed as a percentage, was $16 \%$ in 2016, which is a score comparable with Scottish 5-year-olds, where the CI was $14.2 \%$ in 2014 [6]. A twice as high value of the care index (29.7\%) was noted in Germany in 2016 [11].

Untreated dental caries disease in primary teeth causes cariogenic infection of permanent teeth and its spread to other healthy primary teeth $[18,19]$. Many researchers emphasise that the occurrence of cariogenic flora in primary dentition in a child is considered to be a factor predicting occurrence of lesions in the first permanent molars, which erupt at around the age of 5-6 years. The health condition of the first permanent molars may reflect the future condition of the whole permanent dentition. Permanent dentition in children with dental caries in primary dentition is several times more vulnerable to disease than in healthy children [20].

It is therefore essential to monitor oral health in order to increase awareness among the public with regard to the prevalence and severity of dental caries disease in this age group and to promote educational activities for a future of children free from caries, in accordance with the assumptions of the Alliance for a Cavity-Free Future (ACFF).

\section{CONCLUSIONS}

In the group of 5-year-old children from Mazowieckie Province, in the period from 2011 to 2016, despite the fact that the needs for care were satisfied at 
a similarly low level, the values of indices concerning dental caries and the needs for treatment of extensive carious cavities and complications related to dental pulp were decreased, which may be the effects of the measures taken in order to promote oral health. At the same time, the increase in caries polarisation in primary teeth stresses the necessity of continued monitoring of this population in order to develop tools that will enable a systemic approach distinguishing groups of children that require enhanced preventive and curative measures.

\section{FUNDING}

This work was supported by the Ministry of Health (grant nr 11/1/2016/1210/777).

\section{CONFLICT OF INTEREST}

The authors declare no potential conflicts of interest with respect to the research, authorship, and/or publication of this article.

\section{References}

1. Wierzbicka M, Szatko F, Strużycka I, et al. Monitoring Zdrowia Jamy Ustnej. Stan zdrowia jamy ustnej i jego uwarunkowania oraz potrzeby leczniczo-profilaktyczne dzieci w wieku 5, 7 i 15 lat. Warszawa, 2011.

2. Wyniki badań epidemiologicznych prowadzonych $w$ ramach programu „Monitoring Stanu Zdrowia Jamy Ustnej” w latach: 2008 i 2009, 2010, 2015. Availbale at: www.mz.gov.pl.

3. Oral Health Surveys. Basic Methods $4^{\text {th }}$ ed. WHO, Geneva 2009.

4. Oral Health Surveys. Basic Methods $5^{\text {th }}$ ed. WHO, Geneva 2013.

5. Olczak-Kowalczyk D, Kaczmarek U, Bachanek T, et al. Monitoring Zdrowia Jamy Ustnej. Ocena stanu zdrowia jamy ustnej i jego uwarunkowań w populacji polskiej w wieku 5, 7 i 12 lat w 2016 roku. Warszawa, 2017.

6. National Dental Inspection Programme of Scotland, 2014. Available at: http://ndip.scottishdental.org/wp-content/uploads/2014/ 10/2014-10-28-NDIP-Report.pdf.

7. Vernazza CR, Rolland SL, Chadwick B, Pitts N. Caries experience, the caries burden and associated factors in children in England, Wales and Northern Ireland 2013. Br Dent J 2016; 221 : 315-320.

8. Al-Mutawa SA, Shyama M, Al-Duwairi Y, Soparkar P. Dental caries experience of Kuwaiti kindergarten schoolchildren. Community Dent Health 2010; 27: 213-217.

9. Hysi D, Caglar E, Doroboniku E, et al. Dental caries experience among Albanian pre-school children: a national survey. Community Dent Health 2017; 34: 46-49.

10. Beqzati A, Mega K, Siegenthaler D, et al. Dental health evaluation of children in Kosovo. Eur J Dent 2011; 5: 32-39.

11. Norderyd O, Koch G, Papias A, et al. Oral Health of individuals aged 3-80 years in Jönköping, Sweden during 40 years (1973-2013). II. Review of clinical and radiographic findings. Swed Dent J 2015; 39: 69-86.

12. Grund K, Goddon I, Schüler IM, et al. Clinical consequences of untreated dental caries in 5- and 8-year-olds. BMC Oral Health 2015; $15: 140$

13. Hashim R, Williams SM, Thomson WM, Awad MA. Caries prevalence and intra-oral pattern among young children in Ajman Community Dent Health 2010; 27: 109-113.
14. Al-Malik MI, Holt RD, Bedi R. Prevalence and patterns of caries, rampant caries, and oral health in two- to five-year-old children in Saudi Arabia. J Dent Child (Chic) 2003; 70: 235-242.

15. Wyne AH. Caries prevalence, severity, and pattern in preschool children. J Contemp Dent Pract 2008; 9: 24-31.

16. Kundu H, Patthi B, Singla A, et al. Dental caries scenario among 5, 12 and 15-year-old children in India - a retrospective analysis. J Clin Diagn Res 2015; 9: ZE01-5.

17. Duangthip D, Gao SS, Lo EC, Chu CH. Early childhood caries among 5- to 6-year-old children in Southeast Asia. Int Dent J 2017; 67: 98-106.

18. Šačić L, Marković N, Arslanagić Muratbegović A, et al. The prevalence and severity of early childhood caries in preschool children in the Federation of Bosnia and Herzegovina. Acta Med Acad 2016; 45: 19-25.

19. Caufield PW. Dental caries: an infectious and transmissible disease where have we been and where are we going? N Y State Dent J 2005; 71: 23-27.

20. Leroy R, Declerck D. Impact of caries onset on number and distribution of new lesions in preschool children. Int J Paediatr Dent 2013; 23: 39-47. 